\title{
ENDOGENOUS INSTITUTIONS AND ECONOMIC GROWTH: EVIDENCE FROM CHINA
}

\author{
Zhao Li \\ Glorious Sun School of Business and Management (GSSBM), DongHua University \\ e-mail: lizhao021@163.com
}

ORCID: 0000-0001-6975-3025

\section{Yujing Chu}

Tourism College, Shanghai Normal University, Shanghai, China

e-mail: chuyujing@163.com

(C) $2020 \mathrm{Zhao} \mathrm{Li,} \mathrm{Yujing} \mathrm{Chu}$

This is an open access article distributed under the Creative Commons Attribution-NonCommercial-

-NoDerivs license (http://creativecommons.org/licenses/by-nc-nd/3.0/)

DOI: $10.15611 /$ fins.2020.1.05

JEL Classification: E13, E60, G32

\begin{abstract}
The paper examined how economic institutions affect capital accumulation in the private firms sector through the finance sector and the operation objectives of different ownership firms in a socialist market economy with Chinese characteristics, which extended the neo-classical economic growth method. The Author found that economic institutions were the main factors affecting the efficiency of capital allocation between the private sector and the state-owned sector. Compared with the state-owned sector, economic institutions lead private sector to a decrease in loans and government subsidies through finance sector, and to an increase in its production costs. The evidence suggests that private firms make efforts to hire special human capital to improve economic institutions as a substitute for political capital. Considering that the strategy of China's economic institutions reform was a national promotion which followed after a regional pilot, this paper found that the economic institutions' reform pilot areas had a more significant impact on economic growth.
\end{abstract}

Keywords: economic institutions, ownership discrimination, capital allocation, economic growth.

\section{Introduction}

Since the reform and opening up of China, with the continuous deepening of economic institutions reform, the market of economic institutions has gradually replaced the planned economic institutions and become the main way to regulate economic operations. With the efficiency of production factor allocation and technological progress constantly improving, the Chinese economy has experienced sustained high-speed growth for more than 40 years, which created a miracle of economic growth. The explanation for the miracle was mostly focused on the deepening of physical capital, the continuous accumulation of human capital 
and the continuous improvement of the technical level (Feng, Wang, Liu, and Huang, 2017; Li et al., 2018). However, according to economic indicators, compared with developed countries, the Chinese economy now faces the following problems: low physical capital allocation efficiency (Chen and Wen, 2017; Holz and Yue, 2018), technical progress stagnation and human capital low innovation (Li et al., 2017; Qin, Zhuang, and Yang 2017; Li, Loyalka, Rozelle, and Wu, 2017; Glaeser and Lu, 2018). At present, the phenomenon of medium and high-speed economic growth and low-efficiency factor allocation coexistence cannot be convincingly explained by the new classical economic growth model. For China as a country with constantly improving economic institutions, its economy cannot be explained only by improvement in the efficiency of production factor allocation and the progress of production technology. An in-depth analysis of the characteristics of China's economic operations reveals that the above problems are all related to China's current economic institutions. Based on the above considerations, it is necessary to study the effect of economic institutional changes on the allocation of capital factors and economic growth. How does economic institutional change affect capital allocation and economic growth? What are the factors that influence the changes of the economic institutions? In order to answer the above questions, this paper attempts to introduce institutional factors as an endogenous variable into the extended three-sector economic growth model, to study the impact of economic institutional changes on capital allocation efficiency and economic growth, and to build a more realistic Chinese economic growth model. The economic growth model aims to explain the deep-seated reasons for China's sustained economic growth.

The innovation of this paper was an important attempt concerning the endogenous economic institutions. The paper assumed that the state-owned firm sector had a closer relationship with government departments and had more ease in obtaining government services than the private sector which needed to hire specialized human capital or invest in specific human capital (SHC) to obtain the same government services. The investment of specialized human capital reflected the need for companies to adapt to the institutional environment, and the institutional environment would also evolve with the investment of specialized human capital and economic growth. Based on the extended economic growth model, this paper explained how the endogenous institutional changes affect Chinese economic growth. In order to test whether the extended economic growth model could be used to explain the impact of endogenous institutional changes on China's economic growth, this paper constructed a corresponding econometric model. Through the regression analysis of the panel data regression of 29 provinces from 1997 to 2017, empirically verifying the results of theoretical analysis.

This paper is structured as follows. The second part define the economic institutions, and a review of related literature. The third part concerned extended economic growth through analysing the behaviour of hiring specialized human capital or investing in specific human capital of the private sector under the 
framework of a three-sector economic growth model, and tried to explain the reasons of endogenous institutional changes. The private companies sector hired specialized human capital or invested in specific human capital to adapt to the economic institutional changes, which caused directly or indirectly an improvement in the economic institutions, and then analyzed the existing conditions of the economic equilibrium and the characteristics of a balanced growth path. The fourth part provides the empirical analysis. The conclusion is made in the final part.

\section{Literature review}

Economic growth is not a simple combination of production factors. Only an economic institutional environment that was compatible with economic growth could reveal the advantages in promoting the effect on economic growth of production factors and innovation. Economic institutions as scarce elements were indispensable in economic growth. The impact of economic institutions on economic growth was not one-way. When the economic activities of economic subjects were bound by economic institutions, they would in turn require further improvement of economic institutions, namely institutional changes, to promote technological progress and inspire the vitality of the subjects of economic activity. Institutional changes refer to the adjustment of the formal, informal rules and operational mechanisms in order to adapt to economic development, that is, the dynamic process of the new economic institutions to replace the relatively inefficient old economic institutions (Aoki, 2007).

Most institutional change theories were a one-way logical relationship of "institutional determinism", which emphasized the influence of institutions on economic growth, but neglected the role of economic growth in promoting institutional changes (Magda, Marsden, and Moriconi, 2016; Waring, Goff, and Smaldino, 2017). When the economic institutions were consistent with the direction of economic development, the economic institutions guaranteed the economic interests of the economic activity subjects, and then stimulated the vitality of the economic activity subjects, and thereby promoted economic growth (Kafouros and Aliyev, 2016; Davidson, De Filippi, and Potts, 2018). However, when the economic institutions were inconsistent with the direction of economic development, the economic institutions became a hindrance to economic growth. As a result, the economic institutions would undergo institutional changes under the efforts of the economic activity subjects to adapt to the current economic development direction and thus promoted further economic growth. Therefore, institutional changes were a cyclical cumulative causal process of institutional and economic growth (Chen, Gao, and Chen, 2017; Hartmann, Guevara, Jara-Figueroa, Aristarán, and Hidalgo, 2017; Feola, 2017). 
Taking into account the cyclical cumulative causal relationship, the study of the economic institutional changes began to turn to how to introduce endogenous economic institutional changes into the economic growth model, and how the endogenous institutional changes affect economic growth. The above research gradually became a new direction to explain regional economic growth differences. Under the framework of the new classical economic growth model, Li et al. (2018) extended economic growth through analysing the behaviour of hiring specialized human capital or investing in specific human capital of the private sector under the framework of a three-sector economic growth model, and tried to explain the reasons of endogenous institutional changes. The private sector hired specialized human capital or invested in specific human capital to adapt to the economic institutional changes, which caused directly or indirectly an improvement of the economic institutions. Bodoh-Creed (2019) constructed an endogenous economic institutions selection model for the free choice of agent based on the dynamic game theory, and proved that the public order contract execution institutions was an effective supplement to the private order contract execution institutions. Changes in the public contract institutions would increase the trust of agents and promote economic growth.

The existing literature has the following shortcomings in studying the impact of economic institutions on economic growth: the lack of theoretical consideration of the endogenous changes in the economic institutions in the economic growth model (Cox, 2017). Besides, a single dimension of institutional agency indicators or some comprehensive indicator was usually used in empirical analysis, and most literature studies lacked the test of endogeneity, which made the above results unconvincing. In addition, economic institutional and economic growth were mutually influential, especially for a rapidly developing country like China, it was necessary to build an extended economic growth model to analyse the effect of the endogenous institutional changes on economic growth.

\section{Theoretical model}

\subsection{Household sector}

A representative household consists of a single individual whose descendants continue indefinitely; the family derives its utility from consumption, and its preferences can be expressed by the constant relative risk aversion utility function, whose utility function is:

$$
\mathrm{U}\left(C_{t}\right)=\frac{C_{t}^{1-\theta}}{1-\theta} .
$$

Here, $C_{t}$ denotes household consumption in period $t, 1 / \theta$ the replacement elasticity of the intertemporal consumption, $\theta>1$. 
The initial capital stock of the household sector is zero, and its income is derived from the wages by providing effective labour to the firm sector and the provision of monetary capital to the financial sector. In the period $t$, the household provides $H_{t, \chi}$ effective labour to different ownership firms, and obtains labour income $w_{t, \chi}$, or engage in economic institutional improvement $H_{t, \vartheta}$, and obtain labour income according to wage rate $w_{t, \vartheta}$; and lends $M_{t}$ currency capital to the financial sector at the interest rate $r_{t}$. Labour and capital income are used to consume $C_{t}$ and savings $M_{t}$, which is reflected in the accumulation of monetary capital in the household sector. The household problem is to maximize (1) subject to the following budget constraint:

$$
\dot{M}_{t}=w_{t, S} H_{t, S}+w_{t, P} H_{t, P}+w_{t, \vartheta} H_{t, \vartheta}+r_{t} M_{t}-C_{t} .
$$

Maximization the household sector long-term utility, and its consumption path is:

$$
\frac{\dot{C}_{t}}{C_{t}}=\frac{r_{t}-\rho^{H}}{\theta} \text {. }
$$

As formula (3) shows, the main influencing factors affecting the consumption path of the household sector are the deposit interest rate $r_{t}$, the time preference $\rho^{H}$, and the intertemporal substitution elasticity $\theta$ of consumption.

\subsection{Finance sector}

This section builds a financial sector credit decision model, which derives the mechanism of 'price discrimination' in financial markets under the Chinese characteristics economic institutions.

To simplify the analysis, the financial sector is assumed to be a frictionless intermediary. Its role is to absorb the savings of the household sector at a certain deposit rate per period, fully convert it into firms' credit capital $\left(M_{t}=I_{t}\right)$, and allocate credit capital to different ownership firms at a certain loan interest rate. As an agent of the household sector, its decision-making objective is to maximize financial services, but is influenced by policy factors ${ }^{1}$.

When constructing the utility function of the financial sector, considering the influence of institutional factors, the loan income $\pi_{t, s}$ obtained from the stateowned enterprise and the loan income $\pi_{t, P}$ obtained from the private enterprise are differentiated, that is, the two cannot be completely replaced, the corresponding utility evaluation weight (utility elasticity) is $\mu$ and $1-\mu, 0<\mu<1$. With the continuous improvement of the economic institutions, the influence of policy factors on the credit decision of the finance sector is decreasing. The policy factor is a dynamic variable and an endogenous variable. $G_{t}$ is the influence of policy profits.

${ }^{1}$ See Becker (1957), economic agents are concerned about political demands in addition to 
factors on the utility evaluation of the finance sector, which is related with the economic institutions. To ensure that the model has a stable equilibrium solution, the policy factors is expressed as the function $G_{t}=G\left(\vartheta_{t}\right)$, let $G_{t}$ be a convex function, $0 \leq G_{t}<1, G^{\prime}<0$, indicating that the more perfect the economic institutions, the smaller the impact of policy factors on the finance sector, the higher the independent decision-making of the finance sector. The following is the utility function of finance sector:

$$
U=\pi_{t, S}^{\mu+G_{t}} \pi_{t, P}^{1-\mu}
$$

Here, $\pi_{t, \chi}=\left(1-e_{t, \chi}\right) r_{t, \chi} I_{t, \chi}, \chi=\{S, P\}, S$ denotes state-owned firm, and $P$ private firm. $r_{t, \chi}$ indicates the interest rate of the financial sector loan to the firm sector. The loan interest rate is a function of the loan amount, which satisfies the following relationship: when the financial sector expands the scale of lending, the willingness of the firm sector to pay the loan interest rate will decrease, and vice versa, $\partial r_{t, \chi} / \partial I_{t, \chi}<0 . I_{t, \chi}$ indicates the amount of funds that the financial sector lends to the firm sector. $e_{t, \chi}$ indicates the default rate of the firm sector. The higher the financial sector's mastery of firm credit qualification information, or the closer the financial sector's business relationship with the firm sector, the lower the probability of firm sector default rate. In particular, state-owned firms are mostly large-scale, long-term business, complete financial statements, and long-term cooperation with the financial sector, all of which reduce the degree of information asymmetry between the financial sector and state-owned firms. As a result, the financial sector has a high level of ease in gathering information and monitoring compliance. Most of China's private enterprises are small and medium-sized enterprises, not only financial institutions, and information disclosure mechanisms are not perfect. Under the same conditions, the probability of default of private firms is higher than that of state-owned firms, that is, $e_{t, P}>e_{t, S}$.

The credit capital constraint equation for the financial sector is as follows:

$$
M_{t}=I_{t, S}+I_{t, P} .
$$

Maximizing the utility of the financial sector, then the investment ${ }^{2}$ are:

$$
\begin{aligned}
I_{t, P} & =M_{t} \frac{1-\mu}{1+G_{t}}, \\
I_{t, S} & =M_{t} \frac{\mu+G_{t}}{1+G_{t}} .
\end{aligned}
$$

${ }^{2}$ For a long time, the floating rate of loan interest rates in China's financial sector has been controlled by the central bank, and it has not achieved full marketization, and its floating range is limited. Therefore, the loan interest rate has a small elasticity to the loan scale, which can be approximated to zero, that is, $\varepsilon_{\chi}=0$. 
It can be seen from equations (6) and (7) that in the financial market environment with limited interest rate fluctuations, the scale of financial sector loans to state-owned firms and private firms is not affected by the interest rate of loans, nor the impact of firm loan default rates. It also shows that the finance sector chooses to provide more loans to low-risk, high-yield companies on the basis of comparing the default risks of different firms is a rational market behaviour. However, from equations (6), (7) it can also be seen that the scales of loans of state-owned firms and private firms are affected by policy factors. The scale of loans of state-owned firms is proportional to the directions of their policies, $\partial I_{t, S} / \partial G>0$. The relationship between the scale of loans of private firms is reversed, that is, $\partial I_{t, P} / \partial G<0$. In other words, the more obvious the government's policy tendency toward state-owned firms, the more the distribution of credit resources is biased toward state-owned firms. In the distribution of credit resources in China, there is indeed a phenomenon in which the government intervention replaces the market for credit allocation. This is consistent with the situation of "zombie firms" in which the state-owned firm sector has a large number of loans to survive, and the private firms face "funding difficulties".

\subsection{Endogenous economic institutional change}

Assumption: with economic development, the economic institutions will continue to improve under the existing institutional conditions. In addition, the new interest groups in economic activities - the new private enterprises emerging in China's economic institutions reform - in order to maintain their own interests, will put forward new requirements for property rights protection from institutional arrangements to safeguard their own economic interests. Therefore, the improvement of the economic institutions has an incentive effect on the enterprise. In China's economic operation, state-owned enterprises and government departments have a certain affinity in the public management system, and they have more convenience in obtaining government services than private enterprises. However, in order to obtain the same government services, private enterprises need to hire specialized human capital, such as ex-government personnel and corporate executives, to sort out the relationship with the government, and promote communication and understanding between the two sides. Such an arrangement will reduce the efficiency loss caused by the unperfect economic institutions, and at the same time directly or indirectly induce the improvement of the economic institutions. If private enterprises can improve their own efficiency by hiring special human capital or investing special human capital, and induce the improvement of economic institutions, this arrangement will attract more enterprises to follow suit, thus forming an adaptive, self-reinforcing circulation mechanism. 
Based on the above considerations, this paper considers that the factors affecting economic institutional changes include the special human capital, as well as the economic institutions itself. With regard to the endogenous economic institutional changes model, and the reality of China's economy, this paper extended the Li et al. (2018) model as follows:

$$
\vartheta_{t}=\mathrm{B} \vartheta_{t-1}^{\gamma} H_{t, \vartheta}^{v} .
$$

Here, $\mathrm{B}$ is the economic institutional efficiency, which is a constant; $\gamma$ is the influence factor of economic institutional change, and $v$ is the influence factor of economic institutions improvement. $H_{\vartheta}$ is special human capital hired by private enterprises and satisfies the following conditions: $\vartheta_{H_{t, \vartheta}}>0 ; \vartheta_{H_{t, \vartheta} H_{t, \vartheta}}<0$.

Considering that $G_{t}=G\left(\vartheta_{t}\right): 0 \leq G_{t}<1, G_{\vartheta_{t}}<0$, this paper sets the function of the policy factor $G_{t}$ as:

$$
G_{t}=1-\mathrm{B} \vartheta_{t-1}^{\gamma} H_{t, \vartheta}^{v} .
$$

Satisfies the following conditions: $0 \leq G_{t}<1, G_{H_{\vartheta}}<0$.

\subsection{Firm sector}

There are two types of company ownership in China's current economic institutions, state-owned and private-owned, and their business objectives are different. In view of the differences in business objectives of different ownership firms, this section separately constructs investment decision models for different ownership firms. In order to simplify the model, it is assumed that the products produced by different ownership firms are homogeneous, and the total human resources stock $H_{t}$ is given. The proportion of human capital in state-owned firms and private firms depends on the composition of the two types of firm sector $\varphi$ (the proportion of state-owned firm) or $(1-\varphi)$ (the proportion of private firm). The private sector not only makes capital investment decisions, but also impacts on the share of human capital. The employed human capital is either engaged in the adaptive work of the economic institutions or engaged in the production of products. The private sector comprehensively considers the investment decisions of maximizing economic profits. In addition, it needs to invest in special human capital in order to adapt to institutional conditions and to improve economic efficiency; the more obvious the tendency of the private sector to invest in special human capital, the higher the conversion cost of the special human capital, and the stronger the inclination to replace special human capital with general human capital and physical capital.

\subsubsection{Private firms}

Assuming that the input-output relationship of private enterprises $(P)$ satisfies the Cobb-Douglas form, it can be expressed as: 


$$
Y_{t, P}=K_{t, P} \alpha_{P}\left((1-\varphi) H_{t}\right)^{1-\alpha_{P}} .
$$

$Y_{t, P}$ indicates the output of private firm in period $t ; K_{t, P}$ indicates the capital stock input of private firm in period $t,(1-\varphi) H_{t}$ indicates the human capital investment of private firm in period $t, \alpha_{P}$ and $1-\alpha_{P}$ represent the output elasticity of physical capital $K_{t, P}$ and human capital $(1-\varphi) H_{t}$, respectively.

Considering the affinities of state-owned firm sector and the government sector in the public management system, they have more ease in obtaining government services than the private companies sector which needs to hire special human capital or invest in specific human capital in order to obtain the same government services. The profit function of the private sector refers to a representative private enterprise to hire special human capital in the $t$ period to improve its economic efficiency and general human capital to increase its total economic output. The profit objective of the private sector is to hire special human capital or invest in specific human capital to maximize their net income. The profit function is as follows:

$$
\pi_{t, P}=\vartheta_{t} Y_{t, P}-w_{t, \vartheta} H_{t, \vartheta}-w_{t, P} H_{t, P}-r_{t, P} I_{t, P}-r_{t-1, P} K_{t-1, P} .
$$

Here, $\vartheta_{t}$ is economic efficiency; $w_{t, \vartheta}$ is the wage of special human capital $H_{t, \vartheta}$, and $w_{t, P}$ is the wage of the general human capital $H_{t, P}$. If a general human capital wants to become a special human capital with an expected net income higher than that of general human capital, the general human capital will turn into special human capital, where the expected net income is the wage of special human capital minus the cost of becoming special human capital. To simplify the analysis, it is assumed that the conversion cost from general human capital transferring special human capital is a fixed share of special human capital wage $\eta w_{t, \vartheta}, \eta \in(0,1)$.

To simplify the model, this paper ignores physical capital depreciation. Physical capital accumulation meets the following conditions: $K_{t, P}=I_{t, P}+K_{t-1, P}$.

The human capital of private firm sector meets the following constraints:

$$
(1-\varphi) H_{t, P}=H_{t, P}+H_{t, \vartheta} .
$$

Maximize private firms profits, then the results can be obtained:

$$
\begin{aligned}
& H_{t, \vartheta}=\frac{v(1-\eta)}{\left(1-\alpha_{P}\right)+v(1-\eta)}(1-\varphi) H_{t}, \\
& H_{t, P}=\frac{\left(1-\alpha_{P}\right)}{\left(1-\alpha_{P}\right)+v(1-\eta)}(1-\varphi) H_{t},
\end{aligned}
$$

where $\left(1-\alpha_{P}\right)=\partial Y_{t, P} H_{t, P} / \partial H_{t, P} Y_{t, P}$ represents the output elasticity of general human capital, $v=\partial \vartheta_{t} H_{t, \vartheta} / \partial H_{t, \vartheta} \vartheta_{t}$ is the output elasticity of the special human capital. Therefore, the share of special human capital in the employment of human capital in the private sector is: 


$$
s=\frac{v(1-\eta)}{\left(1-\alpha_{P}\right)+v(1-\eta)} .
$$

It can be seen from equation (15) that the share of special human capital $s$ in the private sector is affected by the human capital conversion cost $\eta$, the general human capital output elasticity $1-\alpha_{P}$ and the special human capital output elasticity $v$. The share $s$ decreases with the increase of fixed $\operatorname{cost} \eta$, which indicates that the higher the fixed cost of general human capital converting into special human capital, the more private firms tend to hire more general human capital to improve their economic output, and that the amount of human capital in the labour market will decrease. The share $s$ increases with the increase of the elasticity of special human capital $v$. This indicates that private firm sector has more incentives to hire more specialized human capital to improve the economic institutions so as to weaken the impact of economic institutions on the economic output, and then the number of special human capital in the labor market increases.

PROPOSITION 1: The private sector employs special human capital to adapt to the economic institutions to increase their economic efficiency and hire general human capital to produce products to increase its economic output. When the labor market is in equilibrium, the proportion of two types of human capital is fixed. When the parameters meet the following conditions: special human capital output elasticity meets $v=0$, human capital conversion cost $\eta=0$, special human capital share $s=0$, private firm sector only employs general human capital for production, at this time the model is a standard new classical economic growth model.

Solving the simultaneous equations (13), (14) and (15), one can obtain:

$$
I_{t, P}=\frac{w_{t, P}}{r_{t, P}} \frac{\alpha_{P}}{\left(1-\alpha_{P}\right)+v(1-\eta)}(1-\varphi) H_{t}-K_{t-1, P} .
$$

It can be seen from equation (16) that the main factors affecting the investment scale $I_{t, P}$ of the private sector include human capital conversion cost $\eta$ and special human capital output elasticity $v$. The larger the human capital conversion cost parameter $\eta$, the more the private sector tends to increase its economic output and then hire more general human capital for production, and the corresponding physical capital investment will increase. The greater the output elasticity of special human capital, the more private firms tend to improve their economic efficiency and then hire more special human capital to adapt to the economic institutions, the relative amount of human capital engaged in production will decrease, and the investment in physical capital will also decrease.

\subsubsection{State-owned firms}

Similar to private firms, the production function of state-owned firms can be expressed as: 


$$
Y_{t, S}=K_{t, S}^{\alpha_{S}}\left(\varphi H_{t}\right)^{1-\alpha_{S}} .
$$

$Y_{t, S}$ indicates the output of state-owned firm in period $t ; K_{t, S}$ indicates the capital stock input of a state-owned firm in period $t, \varphi H_{t}$ indicates the human capital investment of a state-owned firm in period $t, \alpha_{S}$ and $1-\alpha_{S}$ represent the output elasticity of physical capital and human capital, respectively.

State-owned firms also have the characteristics of 'profit' and 'sociality':

1) profit means that state-owned firms pay equal attention to profits in terms of their own development;

2) sociality means that state-owned firms are not only the foundation of the socialist economy with Chinese characteristics, but also have certain policy functions. Therefore, in pursuit of profits, they also pursue the expansion of total assets. The investment objective function of a state-owned firm in period $t$ can be expressed as:

$$
\pi_{t, S}=Y_{t, S}-r_{t, S} I_{t, S}-r_{t-1, S} K_{t-1, S}-w_{t, S} \varphi H_{t}+\phi\left(I_{t, S}+K_{t-1, S}\right) .
$$

Here, $\pi_{t, S}$ is the profit; $Y_{t, S}$ is the added value; $\varphi H_{t}$ and $K_{t-1, S}$ are the human capital stock in period $t$ and physical capital stock in previous period; $I_{t, S}$ is the investment and financing scale; $r_{t, S}$ is the loan interest rate; $w_{t, S}$ is the wage of human capital. Relative to the profit target, the weight of evaluation of the asset size is $\phi$; when $\phi$ rises, a firm will pay more attention to the expansion of asset scale; the change of $\phi$ also reflects that the business objectives of a state-owned firm may be affected by national policy factors.

Similar to the treatment of private firms, this paper ignores the depreciation of physical capital. The physical capital accumulation of a state-owned firm meets the following conditions: $K_{t, s}=I_{t, s}+K_{t-1, S}$.

Maximizing a state-owned firm's profits then the following results can be obtained:

$$
I_{t, S}=\frac{\alpha_{S}}{1-\alpha_{S}} \frac{w_{t, S} \varphi H_{t}}{r_{t, S}-\phi}-K_{t-1, S}
$$

As is shown in equation (19), similar to a private firm, the investment scale of a state-owned firm $I_{t, S}$ is not only affected by capital output elasticity $\alpha_{S}$, loan interest rate $r_{t, s}$ and wage rate $w_{t, s}$, but also by the target weight $\phi$ of the state-owned firm's assets. The greater the target weight $\phi$, the more the state-owned firm's attention to the expansion of asset scale in period $t$, and the corresponding increase in investment. At this time, the investment scale of the state-owned firm will be higher than the scale of investment when pursuing profit maximization, while the investment scale of a state-owned firm will approach the scale of investment with the objectives of maximizing profits. 


\subsection{Comparative static analysis}

According to equations (16) and (19), one can conclude the main factors affecting the investment scales of state-owned firms and private firms are shown in Table 1.

Table 1. Comparative static analysis results

\begin{tabular}{|c|c|c|c|c|c|}
\hline Exogenous variable & $\alpha_{P}$ & $r_{t, P}$ & $w_{t, P}$ & $v$ & $\mathrm{H}$ \\
\hline Endogenous variable & + & - & + & - & + \\
\hline$I_{t, P}$ & $\alpha_{S}$ & $r_{t, S}$ & $w_{t, S}$ & $\phi$ & \\
\hline Exogenous variable & + & - & + & + & \\
\hline$I_{t, S}$ & &
\end{tabular}

Note: "-” indicates negatively correlated; “+” indicates positively correlated.

\subsection{Economic equilibrium}

Since it is assumed that there is no friction in the finance sector and only intermediary services are provided, its function is to completely convert the monetary capital from the household sector into credit capital, and allocate the credit capital to a firm with different ownership with a different loan rate. When the financial market is cleared, the finance sector's loan income from a firm with different ownership is equal to the sum of the household sector's monetary capital interest income, which satisfies the following conditions:

$$
\begin{aligned}
r_{t} M_{t}= & \left(1-e_{t, S}\right)\left(\alpha_{S} K_{t, S}{ }^{\alpha_{S}-1}\left(\varphi H_{t}\right)^{1-\alpha_{S}}+\phi\right) I_{t, S}+ \\
& \left(1-e_{t, P}\right) \alpha_{P} K_{t, P}{ }^{\alpha_{P}-1} H_{t, P}{ }^{1-\alpha_{P}} I_{t, P} .
\end{aligned}
$$

When the financial market is clear, the marginal output of capital and the loan interest rate between firms with different ownership meet the following conditions:

$$
r_{t, P}=r_{t, S}+\phi .
$$

The growth path of household sector consumption obtained by dynamic optimization is:

$$
\begin{aligned}
& \frac{\dot{C}_{t}}{C_{t}}=\left\{\frac{\mu+G_{t}}{1+G_{t}}\left(1-e_{t, S}\right)\left(\alpha_{S} K_{t, S}^{\alpha_{S}-1}\left(\varphi H_{t}\right)^{1-\alpha_{S}}+\phi\right)+\right. \\
& \left.\frac{1-\mu}{1+G_{t}}\left(1-e_{t, P}\right) \alpha_{P} K_{t, P}{ }^{\alpha_{P}-1}\left(s(1-\varphi) H_{t}\right)^{1-\alpha_{P}}\right\} \frac{1}{\theta}-\frac{\rho^{H}}{\theta} .
\end{aligned}
$$

According to equation (22) and the perpetual inventory method of physical capital accumulation, the capital accumulation equations of state-owned firms and private firms are: 


$$
\begin{aligned}
\dot{K}_{t, S} & =\frac{\mu+G_{t}}{1+G_{t}}\left(K_{t, S}{ }^{\alpha_{S}}\left(\varphi H_{t}\right)^{1-\alpha_{S}}+K_{t, P}{ }^{\alpha_{P}}\left(s(1-\varphi) H_{t}\right)^{1-\alpha_{P}}-C_{t}\right), \\
\dot{K}_{t, P} & =\frac{1-\mu}{1+G_{t}}\left(K_{t, S}{ }^{\alpha_{S}}\left(\varphi H_{t}\right)^{1-\alpha_{S}}+K_{t, P}{ }^{\alpha_{P}}\left(s(1-\varphi) H_{t}\right)^{1-\alpha_{P}}-C_{t}\right) .
\end{aligned}
$$

Define $c_{t}=C_{t} / H_{t}$ as the unit of human capital consumption; $k_{t, s}=K_{t, S} / \varphi H_{t}$ as state-owned firm's unit of human capital and physical capital; $k_{t, P}=K_{t, P} /(1-\varphi) H_{t}$ private firm's unit of human capital and physical capital. According to (22), (23), and (24), one can obtain:

$$
\frac{c_{t}}{c_{t}}=\left\{\frac{\mu+G_{t}}{1+G_{t}}\left(1-e_{t, S}\right)\left(\alpha_{S} k_{t, S}{ }^{\alpha_{S}-1}+\phi_{t}\right)+\frac{1-\mu}{1+G_{t}}\left(1-e_{t, P}\right) \alpha_{P} k_{t, P}{ }^{\alpha_{P}-1}\right\} \frac{1}{\theta}-\frac{\rho^{H}}{\theta} .
$$

Then, the capital accumulation equations of state-owned firms and private firms are:

$$
\begin{gathered}
\dot{k}_{t, S}=\frac{\mu+G_{t}}{1+G_{t}}\left(k_{t, S}^{\alpha_{S}}+\frac{s(1-\varphi)}{\varphi} k_{t, P}{ }^{\alpha_{P}}-\frac{1}{\varphi} c_{t}\right), \\
\dot{k}_{t, P}=\frac{1-\mu}{1+G_{t}}\left(\frac{\varphi}{s(1-\varphi)} k_{t, S}^{\alpha_{S}}+k_{t, P}{ }^{\alpha_{P}}-\frac{1}{s(1-\varphi)} c_{t}\right) .
\end{gathered}
$$

The economic system can be described by three differential equations of equations (25), (26), and (27) containing $k_{t, S}, k_{t, P}$ and $c_{t}$.

\subsection{Balanced growth path}

The economic system satisfies the condition at steady state, $\dot{c}_{t} / c_{t}=0, \dot{k}_{t, S} / k_{t, S}=0$ and $\dot{k}_{t, P} / k_{t, P}=0$. At this time, the solution is that the economic system is in equilibrium when consumption is $c_{t}{ }^{*}$, the state-owned firm's unit of human capital and physical capital stock $k_{t, S}{ }^{*}$ and the private enterprise's unit of human capital physical and capital stock $k_{t, P}{ }^{*}$ :

$$
\begin{gathered}
k_{t, S}{ }^{*}=\left(\frac{\alpha_{S}\left(1-e_{t, P}+\frac{\mu+G_{t}}{1+G_{t}}\left(e_{t, P}-e_{t, S}\right)\right.}{\rho^{H}-\phi\left(1-e_{t, P}+\frac{\mu+G_{t}}{1+G_{t}}\left(e_{t, P}-e_{t, S}\right)\right.}\right)^{\frac{1}{1-\alpha_{S}}} . \\
k_{t, P}{ }^{*}=\left(\frac{\alpha_{P}\left(1-e_{t, P}+\frac{\mu+G_{t}}{1+G_{t}}\left(e_{t, P}-e_{t, S}\right)\right.}{\rho^{H}}\right)^{\frac{1}{1-\alpha_{P}}} . \\
c_{t}{ }^{*}=\varphi\left(k_{t, S}{ }^{*}\right)^{\frac{\alpha_{S}}{1-\alpha_{S}}}+\mathrm{s}(1-\varphi)\left(k_{t, P}{ }^{*}\right)^{\frac{\alpha_{P}}{1-\alpha_{P}}} .
\end{gathered}
$$

PROPOSITION 2: Only when the parameter satisfies the following condition $0<\rho^{H}-\phi\left(1-e_{t, P}+\frac{\mu+G_{t}}{1+G_{t}}\left(e_{t, P}-e_{t, S}\right)\right.$, there may be a balanced growth path in the economic system. 
Proposition 4 states: (i) appropriate policy objectives can help resolve market failures and promote economic growth; (ii) state-owned firms should aim at the asset weights in coordination with policy objectives. If Proposition 3 is not met, there is no stable equilibrium point in the economic system, or even if there is an economic equilibrium point, the equilibrium point is extremely unstable, and any slight disturbance will cause the economic system to permanently deviate from the equilibrium point.

The comparative static analysis results are shown in Table 2. According to equations (28) and (29), the factor of influence on the scale of investment in the equilibrium state $k_{t, \chi}{ }^{*}$ is not only affected by the elasticity of capital output $\alpha_{\chi}$, the cost of default of the enterprise $e_{t, \chi}$, the maturity of the financial market $\mu$, human capital conversion $\operatorname{cost} \eta$ and special human capital output elasticity $v$. The larger the human capital conversion cost parameter $\eta$, the more the private sector tends to increase its economic output and then hire more general human capital for production, and the corresponding physical capital investment will increase. The greater the output elasticity of special human capital, the more the private sector tends to improve economic efficiency and then it will hire more special human capital to adapt to the economic institutions, the relative amount of human capital engaged in production will decrease, and the investment in physical capital will also decrease. However, from the perspective of policy and institutional indicators, the loss of economic efficiency of state-owned firms can be compensated by their policy efficiency and institutional efficiency. It is worth noting that the scale of firm investment $k_{t, \chi}{ }^{*}$ in equilibrium state has no relationship with the distribution share of human capital between state-owned firms and private firms.

Table 2. Comparative static analysis results

\begin{tabular}{|c|c|c|c|c|c|c|}
\hline Endogenous variable & $\alpha_{P}$ & $e_{t, P}$ & $\mu$ & $v$ & $\eta$ & \\
\hline$I_{t, P}$ & + & - & + & - & + & \\
\hline Exogenous variable variable & $\alpha_{S}$ & $e_{t, S}$ & $\mu$ & $v$ & $\eta$ & $\phi$ \\
\hline$I_{t, S}$ & + & - & + & - & + & + \\
\hline
\end{tabular}

Note: "-” indicates negatively correlated; “+” indicates positively correlated.

\section{Regression analysis}

\subsection{Econometric model}

According to previous theoretical analysis, the effective capital stock is expressed as $\vartheta_{t} K_{t}$. The reasons include the following: 1) the investment decision of state-owned enterprises is affected by the policy factor $G_{t}$, the latter is related to the 
economic institutions $\vartheta_{t} ; 2$ ) the private enterprise adapts to the economic institutional $\vartheta_{t}$ employment of special human capital, affecting the allocation of physical capital and human capital; 3) institutional environment $\vartheta_{t}$ affects the capital stock and capital use efficiency of the enterprise sector by affecting corporate investment decisions; 4) institutional environment $\vartheta_{t}$ affects the accessibility of enterprises to public services, the latter is reflected in factor productivity. The production function that can construct the total economic output including economic institutional changes as follows:

$$
Y_{t}=A\left(\vartheta_{t} K_{t}\right)^{\alpha} H_{t}^{1-\alpha} .
$$

$Y_{t}$ indicates the output of a private firm in period $t ; K_{t}$ indicates the capital stock input of a firm in period $t, H_{t}$ indicates the human capital investment of a private firm in period $t, \alpha$ and $1-\alpha$ represent the output elasticity of physical capital $K_{t}$ and human capital $H_{t}$, respectively.

Substituting formulas (8) and (15) with the formula (31) gives:

$$
Y_{t}=A\left(\left(\mathrm{~B} \vartheta_{t-1}^{\gamma} \frac{v(1-\eta)}{\left(1-\alpha_{P}\right)+v(1-\eta)}(1-\varphi) H_{t}^{v}\right) K_{t}\right)^{\alpha} H_{t}^{1-\alpha} \text {. }
$$

The logarithm of formula (32) can be obtained:

$$
\ln Y_{t}=\ln A+\alpha \ln \frac{\mathrm{B} v(1-\eta)(1-\varphi)}{\left(1-\alpha_{P}\right)+v(1-\eta)}+\alpha \gamma \ln \vartheta_{t-1}+\alpha \ln K_{t}+(1-\alpha+\alpha v) \ln H_{t} .
$$

Substituting formula (8) with formula (15) and taking the logarithm on both sides to get:

$$
\ln \vartheta_{t}=\ln B+v \ln \frac{\mathrm{B} v(1-\eta)(1-\varphi)}{\left(1-\alpha_{P}\right)+v(1-\eta)}+\gamma \ln \vartheta_{t-1}+v \ln H_{t} .
$$

According to formula (33) and formula (34), the regression model of this paper can be obtained as follows:

$$
\begin{gathered}
\ln Y_{t}=a_{0}+a_{1} \ln \vartheta_{t-1}+a_{2} \ln K_{t}+a_{3} \ln H_{t}+\varepsilon_{t, 1} . \\
\ln \vartheta_{t}=a_{4}+a_{5} \ln \vartheta_{t-1}+a_{6} \ln H_{t}+\varepsilon_{t, 2} .
\end{gathered}
$$

\subsection{Data description}

The research sample of quantitative analysis in this paper was taken from private industrial enterprises and state-owned industrial enterprises. The main data used in this paper were taken from the "China Statistical Yearbook", "China Labor Statistics Yearbook", "China Industrial Economics Statistical Yearbook" and "China Financial Statistics Yearbook". Other parts of the data were further measured based on available data. The period of the time series data in this paper was 1997-2017, because the starting year of the hierarchically educated employee data was available from 1997. The regression analysis of this paper included 
30 provinces (Tibet) as the research objects, and used the panel data and the regression method of simultaneous equations to carry out regression analysis on formulas (35) and (36).

For the economic output, the data of each province were taken from the "Regional Gross Domestic Product" in the "China Statistical Yearbook" over the years. Comparable data of each province: first calculate the total economic output deflator, $P_{t}^{Y}: P_{t}^{Y}=P_{t} / P_{t}^{1997=100}$.

Human capital stock. For the estimation of human capital, refer to $\mathrm{Li}$ et al. (2017). The human capital stock $H_{t}=L_{t} \operatorname{Ln}\left(h_{t}\right)$, where $h_{t}$ is the per capita human capital stock. The employment data of each region were taken from the number of employed persons by three industries in the statistical yearbooks of the provinces over the years. This paper used average educational years $\mu_{t}$ of all employed persons as a proxy variable for the per capita human capital stock $h_{t}$. In Labor Statistics Yearbook, the data on the composition of the national education of employed persons in different regions in 1997-2017 will be divided into seven categories: illiterate, elementary school, junior high school, high school or secondary vocational school, university specialties or higher vocational education, undergraduate and graduate students. Since China's education system has remained basically unchanged between 1997 and 2017, this paper made the following settings for different years of education: illiterate ( 0 years), primary school (6 years), junior high school (9 years), high school or secondary school (12 years), college or higher vocational (15 years), undergraduate (16 years) and graduate (19 years). At this time, the average education years of the employed persons is: $\mu_{t}=\sum_{i=0}^{6} m_{a_{i}} \cdot p_{a_{i}}$. Among them, $m_{a_{i}}$ indicates the number of years of education accepted by the employed persons who have obtained the $a_{i}$ degree, and $p_{a_{i}}$ indicates the proportion of the employed persons who have obtained the $a_{i}$ degree in all employed persons as a percentage of the total number of employed persons. For missing data, this paper is supplemented by the interpolation method.

Physical capital stock. There are no data on the physical capital stock in the statistical yearbook. The calculation of the physical capital stock is based on the perpetual inventory method, $K_{t}=I_{t}+K_{t-1}-D_{t}, I_{t}$ is an annual increase in fixed capital investment, $D_{t}$ is capital depreciation. Regarding the comparable price of new fixed capital investment and depreciation of fixed capital, this paper selected the "price index-sub-region fixed asset investment price index" in the China Statistical Yearbook to make a deflator. The calculation of the base period capital stock: assuming the capital depreciation rate is $\delta$, then the fixed capital depreciation period $n=1 / \delta$. According to the perpetual inventory method, the base period capital stock is accumulated year after year from the depreciation of the effective net capital investment in the past $n$ years: $K_{1997}=\sum_{1}^{\mathrm{n}} i I_{1997-\mathrm{n}+i} / n$.

Proxy variable of economic institution. The existing literature on the selection of proxy variables of the economic institutions were mainly measured from four perspectives: the degree of non-nationalization of enterprises; the level of 
marketization; the government's intervention in enterprises; open-up level. The existing research mostly used one of the above four aspects to represent economic institutions, but the use of a single indicator to measure economic institutions was not convincing. The economic institutions were not a single dimension but a combination of multiple aspects. Fan Gang (2011) separated the institutional variables from many economic factors, and proposed the Chinese marketization index. The index synthesizes from five aspects of the relationship between the government and the market, the development of the non-state-owned economy, the degree of development of the market, the degree of development of the factor market, the development of the market intermediary organization, and the legal institutions environment. Combined with the research of Fan Gang et al., this paper used the marketization total index of each province in China as a proxy variable of the economic institutions to study its specific impact on economic growth. Since the data of "China's Provincial Marketization Index Report" prepared by Fan Gang (2016) and others were only updated to 2014, this paper used the data from previous years to obtain the marketization index of each province in 2015-2017 through weighted linear regression. This paper used the "Government-Market Relationship" index as an alternative variable to further test the regression results of this paper.

\subsection{Regression result}

\subsubsection{Benchmark regression}

The regression results of the econometric model in this paper are shown in Table 3 . The goodness-of-fit for both reached $91 \%$, indicating that the overall interpretation of the model is better. It can be seen from the regression results in the second column that the economic institutions of the previous period and the elasticity coefficient of human capital to the current economic institutions are positive, indicating that the previous economic institutions and human capital both have a significant role in promoting the current economic institution, i.e. the economic institutional changes and the improvement of economic institutions improvement construction do exist. This regression further validates the theoretical analysis conclusions of the previous chapters. In 1998-2017, the elasticity of human capital to improve the economic institutions was 0.01 , which means that for every $1 \%$ increase in human capital, the improvement of the economic institutions would increase by $0.01 \%$; the elasticity of the previous economic institutions to the improvement of the economic institutions is 0.91 . Therefore the economic institutions of the previous period changed by $1 \%$, and the economic institutions would be improved by $0.91 \%$. The above analysis also showed that the top-down economic institutions changes contribute more to the improvement of economic institutions than the bottom-up human capital construction to the economic institutions. From the regression results in the third column, it can be 
seen that the capital stock, human capital, and the elasticity coefficient of the economic institutions relative to the total output of the economy are positive, indicating that these factors have a significant role in promoting the long-term growth of the Chinese economy, the effects depended on the factors, And the extent of the effect is different. During the period of 1998 to 2017, the output elasticity of China's human capital was 0.53 , the corresponding physical capital was 0.59 , and economic institutional change 0.20 . In the contribution of economic output, the contribution of human capital and physical capital was similar, but the proportion was obviously greater than the contribution of the economic institutional change. This also reflected the production mode driven by these factors. In addition, the capital allocation efficiency improvement brought by economic institutional change were also gradually playing an important role, while the sum output elasticity of human capital, physical capital and economic institutional change was more than 1, which also reflected the fact that China's economy of increasing returns to scale. The further investment in production factors and the continuous improvement of the economic institutions will inevitably lead to further economic growth, and China's economic growth has potential.

Table 3. Regression results

\begin{tabular}{|l|c|c|}
\hline \multicolumn{1}{|c|}{$\begin{array}{c}\text { Independent } \\
\text { Variable }\end{array}$} & $\ln _{t}$ & $\ln Y_{t}$ \\
\hline $\ln \vartheta_{t-1}$ & $0.91^{* * *}$ & $0.20^{* * * *}$ \\
& $(67.7)$ & $(12.2)$ \\
\hline $\ln H_{t}$ & $0.01^{*}$ & $0.53^{* * * *}$ \\
& $(2.01)$ & $(19.8)$ \\
\hline $\ln K_{t}$ & & $0.59^{* * * *}$ \\
& & $(93.0)$ \\
\hline Cons & $0.09^{*}$ & $-1.88^{* * * *}$ \\
& $(2.09)$ & $(-9.6)$ \\
\hline Hausman Test & $\mathrm{RE}$ & 580 \\
\hline $\mathrm{N}$ & 580 & 0.9857 \\
\hline $\mathrm{R}^{2}$ & 0.9136 & 0.9856 \\
\hline AdjR $\mathrm{R}^{2}$ & 0.9133 & 37782.8 \\
\hline $\mathrm{F}$ & 6100.0 & \\
\hline
\end{tabular}

Notes: $* * *, * *, *$ are the $0.1 \%, 1 \%$ and $5 \%$ of the statistical significant level.

\subsubsection{Subsample regression}

The regression results in Table 3 analyzed the impact of economic institutions on the economic output as a whole. However, each region in China has the same political institution, and a high degree of economic institutions autonomy. The economic development levels in different regions are not the same, just as the economic institutions. In addition, the strategy adopted by China's economic institutions reform was to be promoted after the pilot, In which the priority pilot 
areas were faster than other regions, whether concerning economic institutional changes or economic growth. Therefore, the effect of economic institutions on economic growth was different. This paper divided the provinces into two categories according to the regions opened by the state since the reform and opening up to further verify the impact of economic institutions on economic output. The regions and provinces that were gradually opened since the reform were Guangdong, Fujian, Hainan, Liaoning, Hebei, Tianjin, Shandong, Jiangsu, Shanghai, and Zhejiang. The provinces that had not undergone reform pilots belong to the non-reform pilot area. The regression results are shown in Table 4.

Table 4. Regression results

\begin{tabular}{|l|c|c|c|c|}
\hline \multirow{2}{*}{$\begin{array}{c}\text { Independent } \\
\text { Variable }\end{array}$} & \multicolumn{2}{|c|}{$\ln \vartheta_{t}$} & \multicolumn{2}{c|}{$\ln Y_{t}$} \\
\cline { 2 - 5 } & $\begin{array}{c}\text { Reform pilot } \\
\text { areas }\end{array}$ & $\begin{array}{c}\text { Non-reform } \\
\text { pilot areas }\end{array}$ & $\begin{array}{c}\text { Reform } \\
\text { pilot areas }\end{array}$ & $\begin{array}{c}\text { Non-reform } \\
\text { pilot areas }\end{array}$ \\
\hline $\ln \vartheta_{t-1}$ & $0.87 * * *$ & $0.88^{* * *}$ & $0.30^{* * *}$ & $0.16^{* * * *}$ \\
& $(44.48)$ & $(32.6)$ & $(8.8)$ & $(7.4)$ \\
\hline $\ln H_{t}$ & $0.02^{*}$ & 0.006 & $0.62^{* * *}$ & $0.47^{* * *}$ \\
& $(2.43)$ & $(0.82)$ & $(13.4)$ & $(13.2)$ \\
\hline $\ln K_{t}$ & & & $0.58^{* * *}$ & $0.61^{* * *}$ \\
& & & $(46.0)$ & $(85.3)$ \\
\hline Cons & 0.06 & $0.20^{*}$ & $-2.41^{* * *}$ & $-1.45^{* * *}$ \\
& $(10.6)$ & $(2.8)$ & $(-7.9)$ & $(-5.75)$ \\
\hline Hausman Test & $\mathrm{RE}$ & $\mathrm{RE}$ & $\mathrm{RE}$ & $\mathrm{RE}$ \\
\hline $\mathrm{N}$ & 200 & 380 & 200 & 380 \\
\hline $\mathrm{R}^{2}$ & 0.889 & 0.861 & 0.986 & 0.986 \\
\hline $\mathrm{Adj} \mathrm{R}^{2}$ & 0.888 & 0.859 & 0.986 & 0.986 \\
\hline $\mathrm{F}$ & 3012.5 & 1215.9 & 14056.9 & 25958.9 \\
\hline
\end{tabular}

Notes: $* * *, * * *$ are the $0.1 \%, 1 \%$ and $5 \%$ of the statistical significant level.

According to the second and third columns of the sample regression results, during the period 1997 to 2017, the elasticity of the previous economic institutions in the reform pilot area and the non-reform pilot area were 0.87 and 0.88 , respectively, and the corresponding human capital investment elasticity were 0.02 and 0.006. Differently from national-level, the impact of human capital on the economic institutions was significantly positive and twice as large as the national level in the reform pilot area, while in the non-reform pilot area it was not significant. The above results showed that the improvement of the economic institutions in the reform pilot areas not only had the top-down economic institutional changes, but also the private firm sector hiring human capital to carry out the bottom-up economic institutional improvement. In non-reform pilot areas, the economic institutional changes were mainly top-down. The reason might be that the degree of marketization was not enough, and the improvement of the bottom-up economic institutional changes was not prominent.

According to the fourth and fifth columns of the regression results, during the period 1997 to 2017, the output elasticity of capital investment in the reform pilot 
areas and non-reform pilot areas were 0.58 and 0.61 , respectively, and the corresponding human capital 0.62 and 0.47 , the economic institutions 0.30 and 0.16. Differently from the national-level, the sub-samples showed that the economic institutions' output elasticity of the pilot reform area was nearly twice that of the non-reform pilot area, which also reflected the fact that there was still a certain space for the improvement of the economic institutions in non-reform areas, and also room for releasing China's economic growth potential. The difference in economic development level between the two regions also reflected the success of China's economic institutions reform. The strategy adopted by China to be promoted after piloting was indeed worthy of reference for other developing countries. The above regression results verify the conclusions of the previous methods. The more improved economic institutions, the higher the allocation efficiency of physical capital and the higher the regional economic output effect.

\subsubsection{Endogeneity test}

This paper introduced the lag two-stage economic institutions into the regression model to solve the endogeneity problem of the model. At this time, the econometric model is:

$$
\ln Y_{t}=a_{0}+a_{1} \ln \vartheta_{t-1}+a_{2} \ln \vartheta_{t-2}+a_{3} \ln K_{t}+a_{4} \ln H_{t}+\varepsilon_{t} .
$$

Here, $\ln \vartheta_{t-1}$ represents the first-order lag term of the economic institutions, and $\ln \vartheta_{t-2}$ represents the second-order lag term of the economic institutions. Other variables are similar to the previous ones. The regression results of the econometric model (37) are shown in Table 5.

Table 5. Endogeneity test regression results

\begin{tabular}{|l|c|c|}
\hline \multicolumn{1}{|c|}{ Independent Variable } & $\ln Y_{t}$ & $\ln Y_{t}$ \\
\hline $\ln \vartheta_{t-1}$ & $0.22^{* * *}$ & $0.27 * * *$ \\
& $(12.2)$ & $(9.8)$ \\
\hline $\ln \vartheta_{t-2}$ & & 0.06 \\
& & $(1.5)$ \\
\hline $\ln K_{t}$ & $0.59 * * *$ & $0.58^{* * *}$ \\
& $(93.0)$ & $(81.9)$ \\
\hline $\ln H_{t}$ & $0.53^{* * *}$ & $0.53^{* * *}$ \\
& $(19.8)$ & $(20.1)$ \\
\hline Cons & $-1.81^{* * *}$ & $-1.70 * * *$ \\
& $(-9.6)$ & $(-9.0)$ \\
\hline Hausman Test & $\mathrm{RE}$ & $\mathrm{RE}$ \\
\hline $\mathrm{N}$ & 580 & 580 \\
\hline $\mathrm{R}^{2}$ & 0.986 & 0.986 \\
\hline $\mathrm{Adj} \mathrm{R}^{2}$ & 0.986 & 0.986 \\
\hline $\mathrm{F}$ & 39756.8 & 39968.2 \\
\hline
\end{tabular}

Notes: $* * *, * *, *$ are the $0.1 \%, 1 \%$ and $5 \%$ of the statistical significant level. 
The regression results showed that when the economic institutions were delayed by one period, the sign and significance of the regression coefficient of the main explanatory variables were not changed, and the impact of the lag economic institutions was also significantly positive; in the lag two period economic institutions, the first order lag was significantly positive, while the coefficient of the lag 2 was positive but not significant, and the sign and significance of other explanatory variables were not changed. Based on the above results, it is effective to use the economic system to bring the regression model into the regression model to control the endogeneity problem. The sign and significance of the coefficients of the main explanatory variables in the regression model were basically consistent with the benchmark regression model, indicating that the model results were still valid after controlling the endogeneity problem, and the economic institutions had significant economic output. Based on the above analysis, there was no endogeneity problem in the benchmark regression analysis.

\subsubsection{Robust test}

"Government-market relationship" and "market-oriented total index" showed similarity in the Fan Gang Index, which referred to the improvement of the economic institutions. Based on the above considerations, this paper used the "Government-Market Relationship" index as an alternative variable to the "Marketing Total Index" to further robust test of benchmark regression. The regression results were shown in Table 6.

Table 6. Robust test regression results

\begin{tabular}{|l|c|c|}
\hline \multicolumn{1}{|c|}{$\begin{array}{c}\text { Independent } \\
\text { Variable }\end{array}$} & $\ln \vartheta_{t}$ & $\ln Y_{t}$ \\
\hline $\ln \vartheta_{t-1}$ & $0.90^{* * *}$ & $0.10^{* * *}$ \\
& $(51.5)$ & $(5.4)$ \\
\hline $\ln H_{t}$ & $0.009^{*}$ & $0.54^{* * *}$ \\
& $(2.21)$ & $(17.9)$ \\
\hline $\ln K_{t}$ & & $0.63^{* * *}$ \\
& & $(101.4)$ \\
\hline Cons & $0.12^{* *}$ & $-2.00^{* * *}$ \\
& $(2.09)$ & $(-9.4)$ \\
\hline Hausman Test & $\mathrm{RE}$ & $\mathrm{RE}$ \\
\hline $\mathrm{N}$ & 580 & 580 \\
\hline $\mathrm{R}^{2}$ & 0.856 & 0.983 \\
\hline $\mathrm{Adj} \mathrm{R}^{2}$ & 0.856 & 0.983 \\
\hline $\mathrm{F}$ & 3436.4 & 33268.4 \\
\hline
\end{tabular}

Notes: ***,**,* are the $0.1 \%, 1 \%$ and $5 \%$ of the statistical significant level. 
It can be seen from the regression results in the second column that the economic institutions of the previous period had a significant positive relationship with the current economic institutions at $5 \%$ level, indicating that the previous economic institutions had a significant role in improving the current economic institutions, while in column 3 that the economic institutions had a significant positive relationship with the total output of the economy at the level of $0.1 \%$, indicating that the economic institutions had a significant role in promoting the long-term growth of the Chinese economy. The above regression results were consistent with the "Marketing Total Index" as the regression result of the proxy variable, indicating that the theoretical model of this paper was stable, and the economic institutions had a significant role in promoting economic growth.

\section{Conclusion}

Under the framework of the new classical economic growth model including the finance sector and different ownership firms' sectors - the private sector and the state-owned sector, this paper analysed the private sector's investment behaviour of special human capital, which caused the improvement of China's socialist market economic institutions. Based on the extended economic growth, the authors attempted to explain the effect of the endogenous institutional changes on the economic growth. Through the regression analysis of the panel data regression of 30 provinces from 1997 to 2017, the authors found that the improvement of economic institutions included the influence of economic institutional changes and special human capital, and the contribution of economic institutional changes was greater than that of special human capital, for China the economic institutions improvement was mainly in the top-down mode. The economic institutional changes did have a positive effect on economic growth, but its contribution was lower than those of human capital and physical capital, which also reflected the production mode driven by factors. The improvement of capital allocation efficiency brought by the improvement of the economic institutions was also gradually playing an important role in promoting economic growth. In addition, the sum of the output elasticity of human capital, physical capital and economic institutional changes was greater than 1, which reflected China's economy increasing returns to scale. The further investment in production factors and the continuous improvement of the economic institutions would inevitably lead to further economic growth, and China's economic growth still had potential. The improvement of the economic institutions in the reform pilot areas were far greater than the non-reform pilot areas. The difference in economic development level between the two regions also reflected the success of China's economic institutions reform. The strategy adopted by China to promote reforms after the piloting schemes was indeed an economic development strategy worthy of reference for other developing countries. 
The shortcomings of this paper: first the definition of economic institutions in this paper was limited to the impact of firm property ownership on firm sector decision-making objectives and the impact of market coordination and government-led mixed mode on economic behaviour. Although these two factors had a significant effect on China's economic operation, they could not cover all the characteristics of the economic institutions, making the study of the endogenous institutional changes not comprehensive and thorough, and needs to be improved in the subsequent research. Second, in order to simplify the model, the paper first introduced the finance sector as a single agent of the family sector, and then provided intermediary services for the non-financial enterprise sector in the process of converting monetary capital into credit funds, without giving further consideration to heterogeneity characteristics of the finance sector. The hypothesis should be less stringent in subsequent research. Third, the economic institutions as a framework of a series of economic activities and behavioural norms, involving a wide range, meant it was difficult to carry out a complete quantitative measure. How to more comprehensively quantify the economic institutional factors is also the focus of further research.

\section{Competing interests:}

Conflict of Interest: I declare that I have no financial and personal relationships with other people or organizations that can inappropriately influence our work, there is no professional or other personal interest of any nature or kind in any product, service and/or company that could be construed as influencing the position presented in, or the review of the manuscript entitled

Ethical approval: this article does not contain any studies with human participants performed by any of the authors.

\section{References}

Aoki, M. (2007). Endogenizing institutions and institutional changes. Journal of Institutional Economics, 3(1), 1-31.

Bodoh-Creed, A. L. (2019). Endogenous institutional selection, building trust, and economic growth. Games and Economic Behavior, 114, 169-176.

Chen, C., Gao, J., and Chen, J. (2017). Institutional changes, land use dynamics, and the transition of rural settlements in suburban China: A case study of Huishan District in Wuxi city. Habitat International, 70, 24-33.

Chen, K., and Wen, Y. (2017). The great housing boom of China. American Economic Journal: Macroeconomics, 9(2), 73-114.

Cox, G. W. (2017). Political institutions, economic liberty, and the great divergence. The Journal of Economic History, 77(3), 724-755.

Davidson, S., De Filippi, P., and Potts, J. (2018). Blockchains and the economic institutions of capitalism. Journal of Institutional Economics, 14(4), 639-658. 
Feng, C., Wang, M., Liu, G. C., and Huang, J. B. (2017). Sources of economic growth in China from 2000-2013 and its further sustainable growth path: A three-hierarchy meta-frontier data envelopment analysis. Economic Modelling, 64, 334-348.

Feola, G. (2017). Adaptive institutions? Peasant institutions and natural models facing climatic and economic changes in the Colombian Andes. Journal of rural studies, 49, 117-127.

Glaeser, E. L., and Lu, M. (2018). Human-capital externalities in China (No. w24925). National Bureau of Economic Research.

Hartmann, D., Guevara, M. R., Jara-Figueroa, C., Aristarán, M., and Hidalgo, C. A. (2017). Linking economic complexity, institutions, and income inequality. World Development, 93, 75-93.

Holz, C. A., and Yue, S. U. N. (2018). Physical capital estimates for China's provinces, 1952-2015 and beyond. China Economic Review, 51, 342-357.

Kafouros, M., and Aliyev, M. (2016). Institutional development and firm profitability in transition economies. Journal of World Business, 51(3), 369-378.

Li, H., Loyalka, P., Rozelle, S., and Wu, B. (2017). Human capital and China's future growth. Journal of Economic Perspectives, 31(1), 25-48.

Li, Z., Chu, Y., and Wu, G. (2017). The impact of sectoral composition change and human capital on total factor productivity. Agro Food Industry Hi-Tech, 28(1), 701-705.

Li, Z., Chu, Y., and Wu, G. (2018). Influence of endogenous technological progress on economic output in China. Journal of Advanced Oxidation Technologies, Vol. 22, No. 2, 201802774.

Li, Z., Chu, Y., and Gao, T. (2018). Economic growth with endogenous economic institutions. Macroeconomic Dynamics, 1-15.

Magda, I., Marsden, D., and Moriconi, S. (2016). Lower coverage but stronger unions? Institutional changes and union wage premia in Central Europe. Journal of Comparative Economics, 44(3), 638-656.

Qin, X., Zhuang, C. C., and Yang, R. (2017). Does the one-child policy improve children's human capital in urban China? A regression discontinuity design. Journal of Comparative Economics, 45(2), 287-303.

Waring, T. M., Goff, S. H., and Smaldino, P. E. (2017). The coevolution of economic institutions and sustainable consumption via cultural group selection. Ecological economics, 131, 524-532.

\section{INSTYTUCJE ENDOGENICZNE A WZROST GOSPODARCZY NA PRZYKLADZIE CHIN}

Streszczenie: W artykule zbadano wpływ instytucji gospodarczych na akumulację kapitału w sektorze prywatnym przez sektor finansowy, a także cele działalności gospodarczej firm o zróżnicowanej strukturze własności w ramach socjalistycznej gospodarki rynkowej na przykładzie Chin w odniesieniu do neoklasycznej metody wzrostu gospodarczego. Autor stwierdził, że instytucje gospodarcze były głównym czynnikiem wpływającym na efektywność alokacji kapitału pomiędzy sektorem prywatnym a państwowym. Badania sugerują, że prywatne firmy starają się zatrudniać specjalistyczną kadrę w celu ulepszenia instytucji gospodarczych, aby zastąpić kapitał polityczny. Biorąc pod uwagę, że strategia reformy chińskich instytucji gospodarczych miała skalę ogólnokrajową po przeprowadzonym regionalnym projekcie pilotażowym, autor stwierdza, że reforma instytucji gospodarczych w regionach miała istotny wpływ na wzrost gospodarczy.

Słowa kluczowe: instytucje gospodarcze, dyskryminacja własności, alokacja kapitału, wzrost gospodarczy. 